\title{
PENDIDIKAN KARAKTER DALAM KEARIFAN LOKAL MASYARAKAT CISARUA
}

\author{
Nurjanah, Ira Miranti, Nina Dwiastuty \\ Program Studi Pendidikan Bahasa Inggris \\ Fakultas Bahasa dan Seni Universitas Indraprasta PGRI \\ nurjanah3434@yahoo.com,ade_miranti@yahoo.com,ninadwiastuty@yahoo.com
}

\begin{abstract}
Abstrak
Di Cisarua, Bogor dapat kita temukan turis-turis asing yang berasal dari Timur Tengah yang tinggal sementara maupun menetap. Kehadiran mereka di desa Choblong membuat masyarakat khawatir, karena para turis tersebut juga membawa budaya asli mereka yang mungkin dapat memengaruhi budaya lokal masyarakat. Ternyata masyarakat Choblong yang beragama Islam telah menerapkan kekuatan karakter pada masyarakatnya walaupun mereka tidak menyadari kondisi, hal ini dapat dilihat pada aktivitas keagamaan rutin dan tertentu, seperti pengkajian Al Qur'an. Berdasarkan situasi ini, tujuan artikel ini ditulis adalah untuk mendeskripsikan kearifan lokal yang dimiliki masyarakat dan pendidikan karakter yang mewakili setiap aktivitas.
\end{abstract}

Kata kunci: Pendidikan Karakter, Kearifan Lokal

\begin{abstract}
In Cisarua - Bogor, there are so many tourists from the Middle East who temporarily or permanently stay. Their presence in the surrounding of Choblong village makes the indegenious worry since the tourists bring also their culture which may influence local culture. It turns out that Choblong's villagers who inherit Islam religious have actually implemented the strengthen of its villager's characters though they do not realize this condition, through certain and routine religious activities, like Qur'an reciting. Based on this situation, this article is aimed at describing what local wisdoms the villagers have and what character's values represented in each activities.
\end{abstract}

Keywords: Character Building and local wisdom

\section{PENDAHULUAN}

Pendidikan karakter sangat penting untuk ditanamkan pada anak semenjak dini. Pendidikan karakter, sangatlah penting untuk diajarkan dan diterapkan bahkan mutlak sangat diperlukan bukan hanya pada lingkungan sekolah saja, tetapi juga pada lingkungan rumah dan juga lingkungan sosial. Menurut Kementrian Pendidikan dan Kebudayaan (dikutip dari www.kemendikbud.go.id., 2011), ada 18 nilai-nilai yang harus disisipkan dalam proses pendidikan di Indonesia. Seperti yang diungkapkan Syarbini (2012:26) 18 nilai tersebut antara lain, religius, jujur, toleransi , disiplin, kerja keras, kreatif, mandiri, demokratis, rasa ingin tahu, semangat kebangsaan, cinta tanah air, menghargai prestasi, bersahabat/komunikatif, cinta damai, gemar membaca, peduli lingkungan, peduli sosial, dan tanggung jawab. Adapun ke-18 nilai- nilai yang dikembangkan dalam pendidikan 
karakter tersebut jika dideskripsikan berdasarkan kutipan dari Kemendikbud (www.kemendikbud.go.id.,2011)

sebagai berikut:

1. Religius yaitu sikap dan perilaku yang patuh dalam melaksanakan ajaran agama yang dianutnya, toleran terhadap pelaksanaan ibadah agama lain, dan hidup rukun dengan pemeluk agama lain.

2. Jujur yaitu perilaku yang didasarkan pada upaya menjadikan dirinya sebagai orang yang selalu dapat dipercaya dalam perkataan, tindakan, dan pekerjaan.

3. Toleransi yaitu sikap dan tindakan yang menghargai perbedaan agama, suku, etnis, pendapat, sikap, dan tindakan orang lain yang berbeda dari dirinya.

4. Disiplin yaitu tindakan yang menunjukkan perilaku tertib dan patuh pada berbagai ketentuan dan peraturan.

5. Kerja Keras yaitu perilaku yang menunjukkan upaya sungguhsungguh dalam mengatasi berbagai hambatan belajar dan tugas, serta menyelesaikan tugas dengan sebaikbaiknya.

6. Kreatif yaitu berpikir dan melakukan sesuatu untuk menghasilkan cara atau hasil baru dari sesuatu yang telah dimiliki.

7. Mandiri yaitu sikap dan prilaku yang tidak mudah tergantung pada orang lain dalam menyelesaikan tugas.

8. Demokratis yaitu cara berpikir, bersikap, dan bertindak yang menilai sama hak dan kewajiban dirinya dan orang lain.

9. Rasa Ingin Tahu yaitu sikap dan tindakan yang selalu berupaya untuk mengetahui lebih mendalam dan meluas dari sesuatu yang dipelajarinya, dilihat, dan didengar.
10. Semangat Kebangsaan yaitu cara berpikir, bertindak, dan berwawasan yang menempatkan kepentingan bangsa dan Negara di atas kepentingan diri dan kelompoknya.

11. Cinta Tanah Air yaitu cara berpikir, bersikap, dan berbuat yang menunjukkan kesetiaan, kepedulian, dan penghargaan yang tinggi terhadap bahasa, lingkungan fisik, sosial, budaya, ekonomi, dan politik bangsa.

12. Menghargai Prestasi yaitu sikap dan tindakan yang mendorong dirinya untuk menghasilkan sesuatu yang berguna bagi masyarakat, dan mengakui serta menghormati keberhasilan orang lain.

13. Bersahabat/Komunikatif yaitu tindakan yang memperlihatkan rasa senang berbicara, bergaul, dan bekerjasama dengan orang lain.

14. Cinta Damai yaitu sikap, perkataan, dan tindakan yang menyebabkan orang lain merasa senang dan aman atas kehadiran dirinya.

15. Gemar Membaca yaitu kebiasaan menyediakan waktu untuk membaca berbagai bacaan yang memberikan kebajikan bagi dirinya.

16. Peduli Lingkungan yaitu sikap dan tindakan yang selalu berupaya mencegah kerusakan pada lingkungan alam di sekitarnya, dan mengembangkan upaya-upaya untuk memperbaiki kerusakan alam yang sudah terjadi.

17. Peduli Sosial yaitu sikap dan tindakan yang selalu ingin memberi bantuan kepada orang lain dan masyarakat yang membutuhkan.

18. Tanggung Jawab yaitu sikap dan perilaku seseorang untuk melaksanakan tugas dan kewajibannya yang seharusnya dia lakukan terhadap diri sendiri, masyarakat, lingkungan (alam, 
sosial, dan budaya), Negara, dan Tuhan Yang Maha Esa.

Soedarsono (2009: 131-132) menyebutkan pembangunan karakter merupakan proses yang panjang, untuk itu memerlukan pembiasaan. Pembiasaan untuk selalu berusaha berbuat baik, pembiasaan pada diri sendiri agar selalu berlaku jujur, bersikap pemberani/ ksatria, membudayakan bersikap malu menghindari berbuat curang, menghindari sikap malas, tidak pernah membiarkan lingkungannya kotor. Karakter bagi setiap individu tidak terbentuk secara langsung, namun harus melalui sebuah pembiasaan dan dilatih secara berkesinambungan dan proporsional agar mencapai bentuk dan kekuatan yang ideal dan diinginkan. Yang dimaksud dengan Pendidikan berbasis kearifan lokal adalah pendidikan yang lebih didasarkan kepada pengayaan nilai- nilai kultural (budaya). Pendidikan ini mengajarkan kepada para peserta didik untuk dapat selalu dekat dengan situasi konkrit yang mereka hadapi sehari- hari. Dengan kata lain pendidikan yang berbasis pada kearifan lokal ini mengajak pada para peserta didik untuk selalu dekat dan menjaga keadaan sekitar masyarakat yang bersifat nilai yang berada di dalam lokal masyarakat tersebut. Pada era globalisasi sekarang ini, segala macam informasi yang berasal dari belahan dunia manapun dapat masuk dengan mudah dan akan sangat sulit untuk dibendung. Dengan adanya fenomena ini, para generasi muda yang berada di lingkungan masyarakat dapat dengan mudah mengetahui dan menyerap informasi dan budaya dari belahan negara lain. Dan dalam kondisi dan keadaan seperti inilah suatu karakter bangsa akan sangat diperlukan. Jikalau suatu bangsa memiliki karakter yang kuat maka generasi muda tidak akan bisa terpengaruh oleh budaya asing yang tidak sesuai dengan budaya Indonesia dan begitupula dengan tata nilai. Dimana jika suatu bangsa memiliki karakter diri yang kuat maka nilai-nilai keluhuran yang sejak dulu telah ada tidak akan pernah tergeser atau bahkan terhapuskan. Namun, jika karakter kuat tidak dimiliki oleh masyarakat dalam suatu bangsa, maka generasi muda dan tata nilai yang ada akan dengan mudah tergerus oleh hadirnya budaya negara-negara lain. Oleh karenanya untuk membentengi/ melindungi generasi muda supaya tidak mudah ikut serta dalam arus globalisasi maka diperlukan pembangunan karakter yang sangat kuat. Pembangunan karakter yang kuat bisa dilakukan melalui pendidikan, baik pendidikan formal, informal maupun pendidikan non formal karena pada dasarnya mendidik adalah mengubah ke seseorang ke kondisi lebih baik sehingga karakter kuat akan terbentuk dalam dirinya. Karakter kuat akan menjadi filter seseorang untuk menyaring informasi dan budaya asing yang masuk. Oleh karenanya, agar tercipta pendidikan bangsa yang berkarakter maka pendidikan karakter menjadi sangat penting untuk dilaksanakan karena pendidikan karakter dapat membentuk atau mengubah karakter generasi muda bangsa menjadi lebih baik. Dengan memiliki generasi muda yang berkarakter bangsa yang kuat maka suatu bangsa akan semakin maju peradabannya dengan budaya leluhur yang terjaga kelestariannya. Dengan semakin derasnya arus globalisasi dan modernisasi dapat mengakibatkan terkikisnya rasa kecintaan terhadap budaya lokal, sehingga kebudayaan lokal yang telah menjadi warisan dari para leluhur dapat terinjak-injak oleh hadirnya budaya asing. Hal ini ini menjadi suatu kekhawatiran berkaitan 
dengan begitu banyaknya para turis yang berasal dari Timur Tengah yang menetap sementara di daerah kampung Choblong desa Cibereum Cisarua Bogor. Berdasarkan latar belakang tersebut kami memberikan pengenalan tentang pendidikan karakter melalui kearifan lokal di RT 002 dan RT 003 kampung Choblong desa Cibereum Cisarua Bogor.

\section{METODE PELAKSANAAN}

Pemilihan mitra kegiatan ini didasarkan atas kebutuhan mitra akan nilai-nilai yang terkandung pada pendidikan karakter untuk dikenalkan kembali melalui kearifan lokal di RT 002 dan RT 003 kampung Choblong desa Cibereum Cisarua Bogor. Pendekatan yang kami lakukan dalam kegiatan peng-abdian masyarakat ini adalah dengan melakukan hal-hal di bawah ini:

1. Presentasi pengenalan tentang 18 nilai yang terkandung pada pendidikan karakter yang terkandung dalam kearifan lokal kampung Choblong desa Cibereum Cisarua Bogor.

2. Tanya jawab tentang 18 nilai yang terkandung dalam pendidikan karakter.

\section{HASIL DAN PEMBAHASAN}

Hasil kegiatan ini adalah masyarakat sangat antusias ketika kami memperkenalkan delapan belas nilai dalam pendidikan karakter. Mereka sangat antusias bertanya tentang ke-18 nilai tersebut dan tentang cara menerapkannya dalam kehidupan sehari-hari. Dalam sesi Tanya jawab pun terungkap bahwa kegiatan yang mereka jalani selama ini adalah penerapan dari ke-18 nilai pendidikan karakter tersebut.
Dengan mengenalkan pendidikan karakter pada masyarakat di RT 002 dan RT 003 kampung Choblong desa Cibereum Cisarua Bogor maka kekhawatiran yang berkaitan dengan begitu banyaknya para turis yang berasal dari Timur Tengah yang menetap sementara di sekitar daerah kampung Choblong desa Cibereum Cisarua Bogor dapat terhapus.

Hal lainnya yang juga sangat penting adalah, keluarga yang merupakan pusat pembangunan karakter utama dan pertama. Orang tua tidak dapat menuntut sekolah dengan seenaknya jika anaknya berkelakuan buruk, jika orang tua tidak pernah memantau dan mengajar langsung pendidikan karakter pada anak-anaknya. Demikian pula masyarakat sekitar tempat anak bermain dan bersosialisasi, meniru, meneladani dan menerapkannya dalam diri mereka. Kondisi sosial lingkungan sangat mempengaruhi pembentukan karakter anak. Jika anak tumbuh dalam lingkungan yang keras dan kasar, kemungkinan besar anak menjadi pribadi berkarakter keras, kasar dan arogan. Anak tumbuh dalam lingkungan yang mengedepankan prestasi sebagai prestise, maka secara tidak langsung memicu anak untuk menjadi seseorang yang memiliki karakter kompetitif dalam hal-hal posistif. Sekolah sebagai lingkungan akademis dan sosial bagi anak harus memberikan kondisi yang kondusif bagi pembentukan karakter baik anak. Membudayakan anak agar dapat menghormati orang yang lebih tua, untuk dapat lebih menghargai pendapat orang lain, bersikap demokratis, tidak bersikap diskriminatif dan mendorong para siswa untuk dapat lebih kompetitif dalam berprestasi daripada mementingkan sifat posesif (kepemilikan harta benda). Semua masyarakat baik dari segala kalangan 
orang tua, anak, pihak sekolah harus selalu mengingatkan akan pentingnya pendidikan karakter.

Terkait dengan kearifan lokal yang masih dipegang teguh masyarakat di Kampung Choblong, dapat dideskripsi-kan bahwa aspek keagamaan masih mendominasi banyak kegiatan di kampung tersebut. Contoh sederhana adalah pengajian. Pengajian di Kampung Choblong hampir setiap hari dilakukan oleh para bapak dan ibu baik di pagi hari maupun sore. Ritual harian pengajian ini sudah turun temurun dilakukan oleh masyarakatnya. Dari orang tua dilanjut-kan oleh anakanaknya. Namun yang tidak mereka sadari adalah bahwa pengajian yang mereka lakukan setiap hari ini merupakan budaya yang masih dipegang teguh yang sebenarnya merupakan salah satu cara untuk menguatkan karakter masyarakat kampung tersebut. Nilai pendidikan karakter yang tercermin dalam kegiatan pengajian tersebut antara lain,

1. Religius

Nilai inilah yang paling mereka sadari karena beragama Islam. Menghadiri pengajian menjadi sebuah kewajiban tersendiri di lingkungan masyarakat tersebut.

2. Disiplin

Nilai disiplin tercermin dari kegiatan pengajian. Dengan menghadiri pengajian yang rutin dilakukan dengan waktu yang sudah ditetapkan sesuai kesepakatan bersama, masyarakat harus disiplin tepat waktu mendatangi kegiatan tersebut.

3. Rasa ingin tahu

Dari hasil wawancara dengan masyarakat Kampung Choblong, bisa disimpulkan bahwa mereka ingin mendapatkan ilmu agama baru yang bisa diterapkan dalam kehidup-an sehari-hari karena biasanya guru mengaji membekali mereka dengan ilmu agama baru maupun mengingat-kan ilmu yang sudah dipelajari sebelumnya.

4. Bersahabat/komunikatif

Ketika mendatangi pengajian, masyarakat Kampung Choblong akan melakukan komunikasi dua arah dengan para tetangga sehingga silaturahim tetap terjaga.

5. Gemar membaca

Ketika mendatangi pengajian, mereka akan membaca dan mengkaji Al Qur'an ataupun kitab agama Islam lainnya sehingga mereka akan memperoleh ilmu dari hal tersebut.

6. Peduli lingkungan

Pengajian dilaksanakan baik di masjid, madrasah ataupun rumah warga. Dengan menghadirinya, masyarakat secara langsung peduli terhadap lingkungan karena menghidupkan rumah ibadah dengan kegiatan positif.

7. Tanggung jawab

$$
\text { Pengajian di Kampung }
$$

Choblong dipimpin oleh seorang guru. Guru tersebut bertanggung jawab dengan ilmu yang diberikan. Sedangkan peserta bertanggung jawab terhadap ilmu yang diterima.

Setelah kami selesai mengadakan pengenalan pendidikan karakter para masyarakat mulai percaya diri bahwa mereka tidak akan kehilangan kearifan lokal yang terdapat di RT 002 dan RT 003 kampung Choblong desa Cibereum Cisarua Bogor selama mereka membentengi diri dan menyaring budaya luar yang tidak sesuai dengan budaya lokal dan hati nurani mereka. 


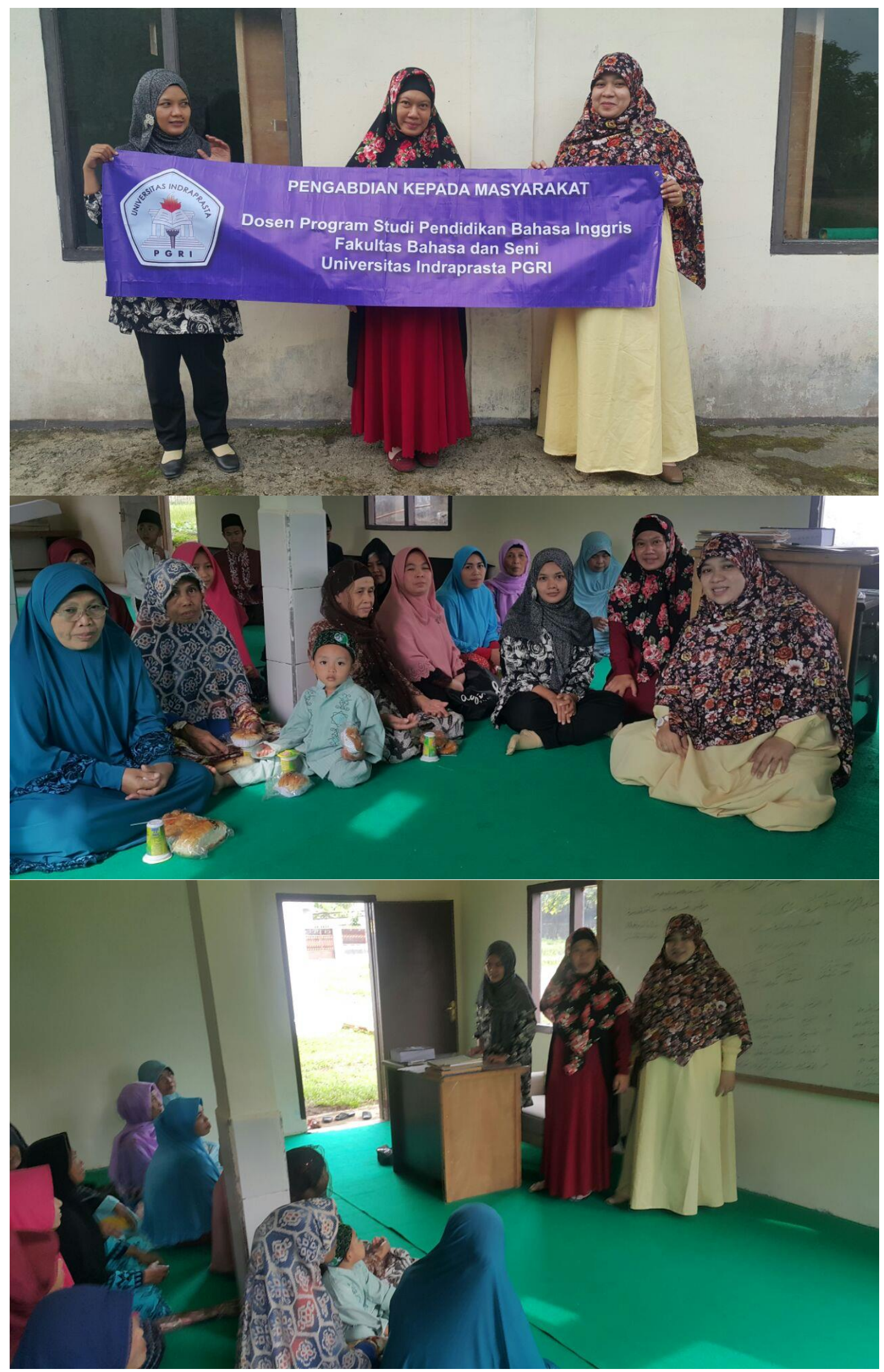




\section{PENUTUP}

Pendidikan karakter sangat penting untuk ditanamkan pada anak semenjak dini. Pendidikan karakter, sangatlah penting untuk diajarkan dan diterapkan bahkan mutlak sangat diperlukan bukan hanya pada lingkungan sekolah saja, tetapi juga pada lingkungan rumah dan juga lingkungan sosial. Pendidikan karakter dalam suatu bangsa sangatlah penting untuk dapat dilaksanakan, karena dapat membentuk atau merubah karakter generasi muda untuk menjadi lebih baik, dan dengan generasi muda yang berkarakter kuat maka karakter dan martabat bangsa pun juga akan bertambah. Derasnya arus globalisasi dan modernisasi dapat mengakibatkan terkikisnya rasa kecintaan terhadap budaya lokal. Dengan mengenalkan pendidikan karakter pada masyarakat di di RT 002 dan RT 003 kampung Choblong desa Cibereum Cisarua Bogor maka kekhawatiran yang berkaitan dengan begitu banyaknya para turis yang berasal dari Timur Tengah yang menetap sementara di daerah kampung Choblong desa Cibereum Cisarua Bogor dapat terhapus. Keluarga merupakan pusat pembangunan karakter (character building) utama dan pertama. Orang tua tidak dapat menuntut sekolah dengan seenaknya jika anaknya berkelakuan buruk, jika orang tua tidak pernah memantau dan mengajar langsung pendidikan karakter pada anak-anaknya. Demikian pula masyarakat sekitar tempat anak bermain dan bersosialisasi, meniru, meneladani dan menerapkannya dalam diri mereka. Kondisi sosial lingkungan sangat mempengaruhi pembentukan karakter anak.
Jika anak tumbuh dalam lingkung-an yang keras dan kasar, kemungkinan besar anak menjadi seseorang yang memiliki pribadi yang berkarakter keras, kasar dan arogan. Anak tumbuh dalam lingkungan yang mengedepankan prestasi sebagai prestise, maka secara tidak langsung memicu anak menjadi pribadi yang berkarakter kompetitif dalam hal-hal posistif. Sekolah sebagai lingkungan akademis dan sosial bagi anak harus memberikan kondisi yang kondusif bagi pembentukan karakter baik anak. Membudayakan agar anak dapat menghormati orang yang lebih tua, untuk dapat menghargai pendapat orang lain, bersikap demokratis, tidak bersikap diskriminatif dan mendorong siswa untuk lebih bisa memiliki sifat kompetitif dalam prestasi daripada mementingkan sifat posesif (kepemilikan harta benda). Semua masyarakat baik dari segala kalangan orang tua, anak, pihak sekolah harus selalu mengingatkan akan pentingnya pendidikan karakter.

\section{DAFTAR PUSTAKA}

\section{Buku:}

Soedarsono, S. (2009). Karakter Mengantar Bangsa dari Gelap Menuju Terang: Karakter Mendorong Kita Hidup dalam Kebahagiaan. Jakarta: PT. Elex Media Komputindo

Syarbini, A. (2012). Buku Pintar Pendidikan Karakter. Jakarta: Prima Pustaka

\section{Internet:}

http//:www.kemendikbud.go.id 